\title{
Microbial Risks in Household UF Purifiers and Disinfection Strategy with Electrolysis
}

\author{
Yucheng Chen ${ }^{1}$, Jian-nan Fu ${ }^{1}$, Yi Wang ${ }^{1, *}$, Jian Ding ${ }^{1}$,Xiaoying Lian ${ }^{1}$, Weizhi Wei ${ }^{1}$, Xiao Chen ${ }^{1,{ }^{*}}$ \\ ${ }^{1}$ College of Defense Engineering, The Army Engineering University of PLA, Nanjing 210007, China
}

\begin{abstract}
The research studied microbial deterioration in household ultrafiltration membrane (UF) purifiers with residence time and anti-bacterial strategy with electrolysis. The pilot test was conducted on a household drinking water purifier. A 72-h stagnation test and a 60-min anti-bacterial test with electrolysis were subsequently done. There were some findings in this study: (1) The level of HPC exceeded the hygienic standard when the stagnation time was more than $3 \mathrm{~h}$. (2) The lag phase of bacterial growth was no more than $12 \mathrm{~h}$ in filters. (3) With the method of electrolysis, microbial contamination induced by water stagnation can be controlled in the acceptable range, which was more efficient than the method of flushing with tap water.
\end{abstract}

\section{Introduction}

The presence of water purifiers has been very large in residents' houses and in the public due to the pursue for high quality drinking water [1]. The purifier plays role in removing hazards and improving the taste of water. UF was proposed by Ministry of Education of PRC for healthy concerns of adolescents However, house-hold purifiers generally run few minutes but stand by for hours or days. Consequently, water stagnation provide time for microbial communities to proliferate [2]. Although UF can prevent almost all bacteria, there are still bacteria exist in the outlets of UF due to leakage points on membrane. Consequently, they act as microbial contamination sources to some extent $[3,4]$.

Moreover, water quality of the small-scale distributed equipment especially the household equipment is generally beyond the supervision of the bureau of health [3], so insufficient attentions were paid to the last meter of water supply. Potable water has become an option for many residents, compared with boiled water. Currently, re-disinfection is a very necessary or even compulsory measure to deal with these problems, for the concern of biological safety. WHO provide guidelines to residents, such as adding chlorine dioxide tablets into water before use [5]. Apparently, re-disinfection is professional but not practical or operational for residents. Besides, redisinfection chemically increases the risks of DPBs

This paper studies the microbial contamination during 3 -d stagnation time. UF outlets at different residence time were collected to detect bacterial regrowth. Bacterial counts were measured after stagnation with the methods of flushing and electrolysis. The purpose of this study is to explore the proliferation and anti-bacterial performance of electrolysis.

\subsection{Experimental plants}

An experimental water treatment plant was applied in this study. The plant consists of sand filtration (SF) unit, GAC unit and a set of ultrafiltration membrane unit, as shown in Fig. 1. Tap water from the drinking water distribution system (DWDS) was used as the influent of the plant.

\subsection{Parameters and detection methods}

In this study, heterotrophic plate counts (HPC), $\mathrm{pH}$, oxidation-reduction potential (ORP), UV254 were measured. HPC was detected on R2A agar. ORP and $\mathrm{pH}$ was detected by measured through ORION 4-Star (Thermo, USA). UV254 and OD600 were detected through visible ultraviolet spectrophotometer TU1810 (PERSEE, China)

\subsection{Pilot test}

The pilot test consisted of the stagnation test anti-bacterial performance test. SF unit and GAC unit were first backwashed before operation. The whole plant ran continuously for $24 \mathrm{~h}$ and then the plant was powered off. Outlets of UF and concentrated water (UFC) were collected at the time of $0,3,6,12,24,36,48,60$, and 72 $\mathrm{h}$ after power off. HPC, ORP, OD600, UV254 and pH were all detected in all samples. The purifier restarted, then outlets from UF and electrolysis were collected every

\section{Materials and Methods}

\footnotetext{
* Corresponding author: wyxqh97@,126.com, shawchen2817@,sina.com
} 


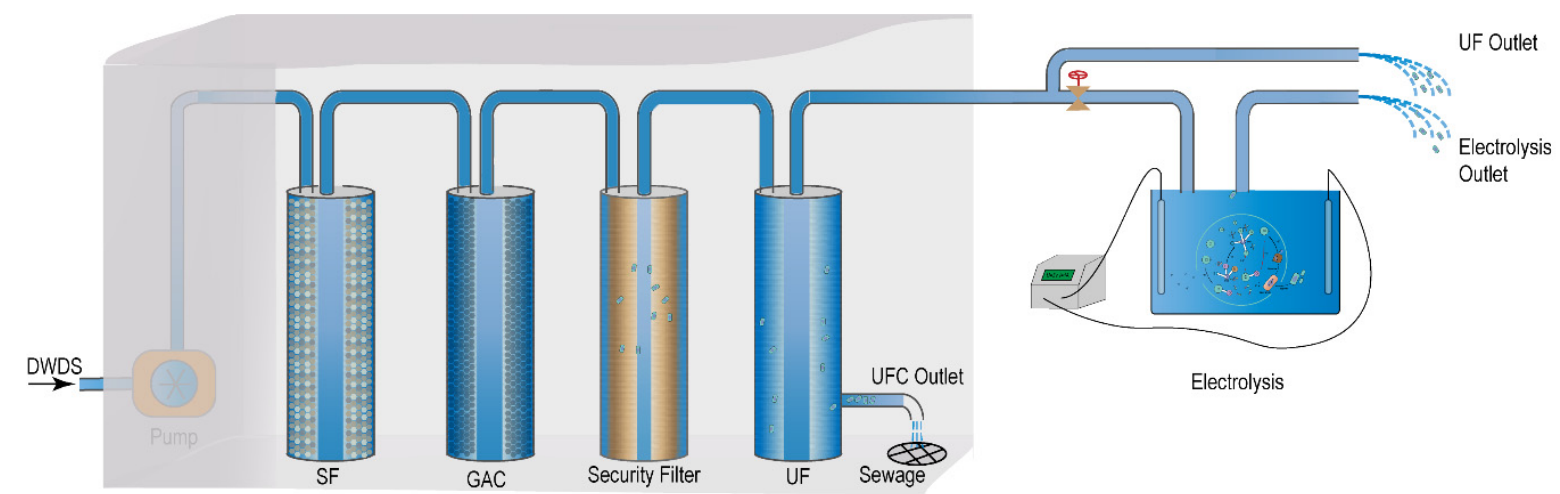

Fig. 1. Schematic of household drinking water treatment plant

15 mins, and HPC were measured. The level of free chlorine was measured in the electrolysed samples.

\subsection{Data processing}

The experimental data was processed using Origin 9.1, ggplot2 and SPSS version 20.0.

\section{Results and Discussion}

\subsection{Bacterial growth with stagnation time}

The value of HPC ranged from $3.36 \times 10^{2}$ to $8 \times 10^{5}$ $\mathrm{cfu} / \mathrm{mL}$, as shown in Fig. 2. Under the condition of continuously flushing, the value of HPC in UF outlet was still over the Chinese hygienic standard of drinking water (HPC $<100 \mathrm{cfu} / \mathrm{mL}$ ). In the first twelve hours, HPC increased very slowly in the lag phase. The exponential phase ranged from the $12^{\text {th }}$ to $72^{\text {th }} \mathrm{h}$ in the UF water while the phase only lasted $24 \mathrm{~h}$ in the UFC water.

The lag phase in the purifier was shorter than that in tap water [7]. The possible reason was that there was no

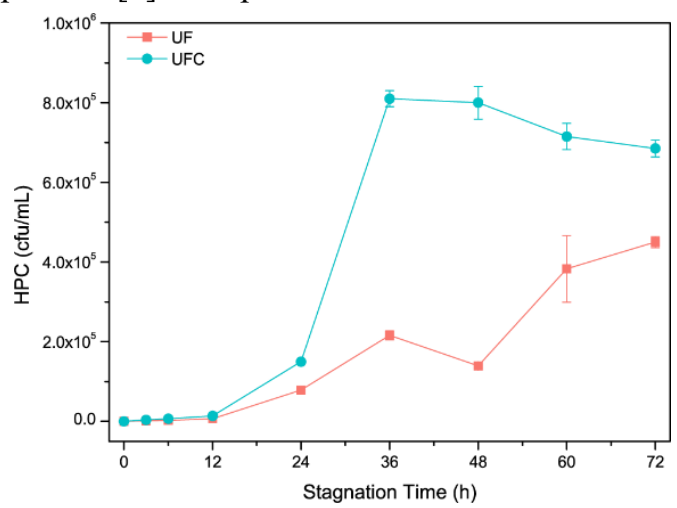

Fig. 2. Bacterial growth with water stagnation disinfection residual in UF and UFC water, so that microbial do not need longer time to recovery and regrow.

During the exponential phase, bacterial cells grew exponentially, as shown in the equation (1), and the generation time $\left(t_{g}\right)$ could be calculated as the equation (2).

$$
\begin{aligned}
& N=N_{0} \times 2^{n} \\
& t_{g}=\Delta t / n
\end{aligned}
$$

in which, $N$ and $N_{0}$ respectively represented the end and the start values of HPC during the exponential phase; $n$ and $\Delta t$ were respectively the generations and the duration of the exponential phase.

To evaluate the average growth rate, the equation (3) was introduced.

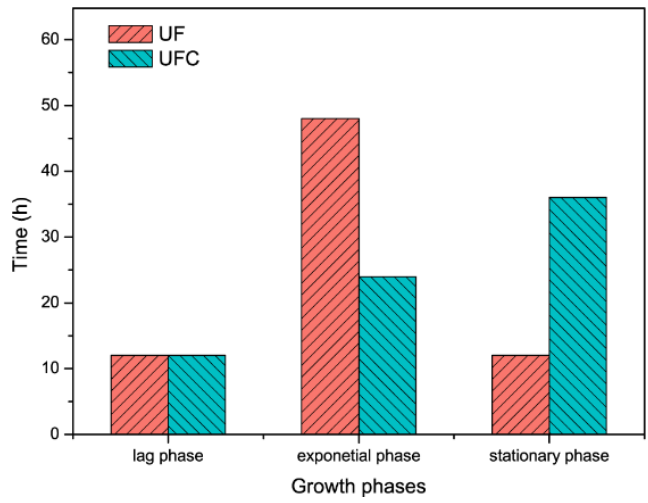

Fig. 3. Duration time of bacterial growth phases

$$
N=N_{0} \times(1+p)^{\Delta t}
$$

Table 1. Bacterial growth indexes in the exponential phase.

\begin{tabular}{|c|c|c|c|}
\hline & $n$ & $t_{g}(\mathrm{~h})$ & $p$ \\
\hline UF water & 10.38 & 4.36 & $16.18 \%$ \\
\hline UFC water & 11.26 & 2.13 & $38.45 \%$ \\
\hline
\end{tabular}

The growth rate was higher in the UFC water than that in the UF water. The possible reason was that the nutrients for bacterial growth were more abundant in the UFC water. As shown in Fig. 3, the exponential phase was shorter in the UFC water than that in the UF water despite that the former had more nutrients. The main reason was that the quorum sensing (QS) [9] effect of the microbial communities.

\subsection{Chemical changes with time}

\subsection{1 $\mathrm{pH}$}


The values of $\mathrm{pH}$ were at the range of 7.25 to $8.15 \mathrm{pH}$ first increased and then decreased slowly. The level of $\mathrm{pH}$ in the UFC water increased more obviously in the first twelve hours and decreased in the following stagnation time zone. The possible reason for increasement was that divalent ion were released from filter cake layer initially [8]. $\mathrm{pH}$ moved to the direction of neutral with increasing residence time.

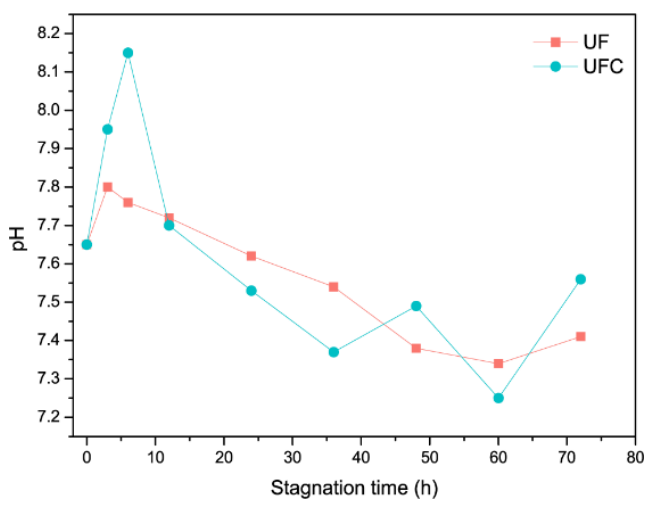

Fig. 4. Changes of $\mathrm{pH}$ in water samples

\subsubsection{Organic matters and ORP}

The organic matter in the polluted water mainly includes an aromatic organic substance such as humic acid and an organic substance having a double bond, and a main absorption band exists in the ultraviolet region near 254 $\mathrm{nm}$. Measuring the magnitude of UV254 can indirectly reflect the extent of organic contamination in contaminated water.

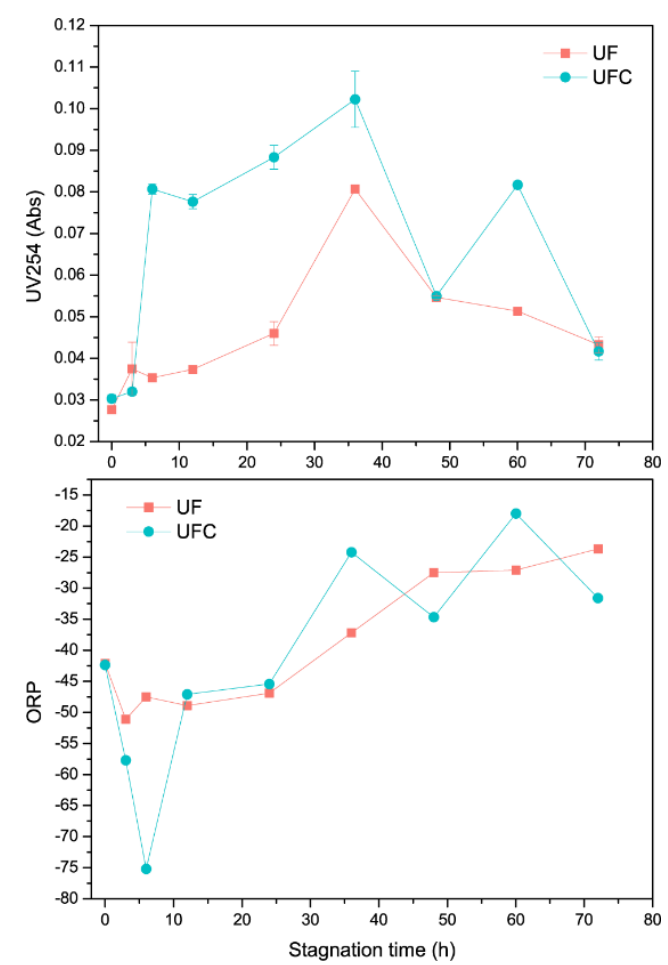

Fig. 6. Changes of ORP in water samples
The level of UV254 was higher in the UFC water than that in the UF water, as shown in Fig. 5 . The regulation of UV254 was similar to the increasement of HPC in the first $36 \mathrm{~h}$. The main pollution in the membrane module was microbial containamation. Microbial communities attached to the filter cake layer and the level of UV254 decreased gradually.

The values of ORP was negative as shown in Fig.6, indicating that the water quality were reductive, and as time went on, the reductiveness gradually diminishes..

\subsection{Correlations between chemical and biological indexes}

Correlations between chemiccal and biological indexes were shown in table 2. HPC was negatively correlated with $\mathrm{pH}$ (7.2-8.15). High level of ESI contributes to the growth of bacteria. Theorically, OD600 was well correlated with HPC [10], but in this study the correlation was not so signficant. The possible reason was that the size of bacterial changed with stagnation time.

Table 2. Correlations between chemical and biological indexes.

\begin{tabular}{|c|c|c|c|c|c|c|}
\hline & $\begin{array}{c}\text { UV } \\
254\end{array}$ & ORP & ESI & HPC & $\begin{array}{c}\text { OD } \\
600\end{array}$ & $\mathrm{pH}$ \\
\hline $\begin{array}{c}\mathrm{UV} \\
254\end{array}$ & 1.000 & 0.236 & 0.343 & 0.472 & 0.840 & -0.224 \\
\hline $\mathrm{ORP}$ & 0.236 & 1.000 & 0.937 & 0.723 & 0.323 & -0.966 \\
\hline $\mathrm{ESI}$ & 0.343 & 0.937 & 1.000 & 0.743 & 0.427 & -0.918 \\
\hline $\mathrm{HPC}$ & 0.472 & 0.723 & 0.743 & 1.000 & 0.532 & -0.674 \\
\hline $\begin{array}{c}\mathrm{ODD} \\
600\end{array}$ & 0.840 & 0.323 & 0.427 & 0.532 & 1.000 & -0.333 \\
\hline $\mathrm{pH}$ & -0.224 & -0.966 & -0.918 & -0.674 & -0.333 & 1.000 \\
\hline
\end{tabular}

\subsection{Anti-bacterial performance of electrolysis}

To evaluate the disinfection effect of electrolysis, the microbial counts were measured with the continuously washed UF water.

The values of HPC all decreased with flushing time, as shown in Fig. 7, and ranged from $5 \times 10^{1}$ to $3.6 \times 10^{5}$ $\mathrm{cfu} / \mathrm{mL}$. The HPC in the electrolysed water decreased to $75 \mathrm{cfu} / \mathrm{ml}$ at the flushing time of $15 \mathrm{~min}$, while the HPC in the control sample (UF) were all largely exceeded 100 $\mathrm{cfu} / \mathrm{ml}$. This indicated that once the UF module was contaminated, it cannot solve the problem of bacteria exceeding the standard only by water washing.

The presence of residual chlorine was detected in the water sample after electrolytic disinfection. This is because under the action of electric energy, the chlorine ions in the water lose electrons and become hypochlorite ions. The electrical energy is converted into the chemical energy of hypochlorite by the redox reaction, which plays a bactericidal role. 


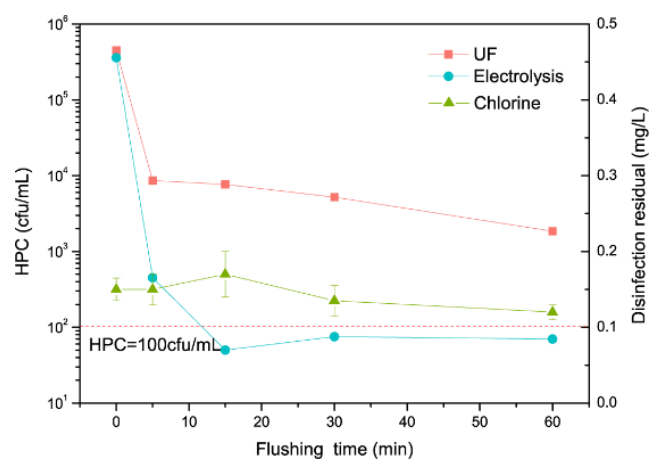

Fig. 7. Anti-bacterial performance of electrolysis

\section{Conclusion}

This paper studied microbial contamination and antibacterial performance with electrolysis.

(1) The level of HPC exceeded the hygienic standard when the stagnation time was more than $3 \mathrm{~h}$.

(2) The lag phase of bacterial growth was no more than $12 \mathrm{~h}$ in filters.

(3) With the method of electrolysis, microbial contamination induced by water stagnation can be controlled in the acceptable range, which was more efficient than the method of flushing with tap water.

\section{References}

1. S. Kim, K.H. Chu, Y.A. Al-Hamadani. The Chem. Eng. J., 335(2018)

2. F. Ling, R. Whitaker, M.W. Lechevallier. ISME J, 2018

3. G.F. Connell, J.C. Routt, B.Macler. J. Am. Water Work Assoc. 92(2000)

4. Chard, A.N., Garn, J.V., Chang, H.H., Clasen, T., Freeman, M.C. J. glob. heal. 9(2019)

5. WHO. Guidelines for Drinking-water Quality 4th Ed. 2011

6. A. Khosravi, Z.H. Rad, N. Amirmahani, A. Nasiri, M. Malakootian. J. Water Chem. Techn. 41(2019).

7. W. Li, J. Zhang, F. Wang, L. Qian, Y. Zhou, W. Qi, J. Chen. Chemosphere, 202(2018).

8. W. Y. Li, X. Wu, W.Q. Qi, F. Yang. J. Tongji Univers. (Natural Science), 36(2008).

9. S. Li, X. Fei, L. Cao, Y. Chi. Sci Total Environ., 691(2019).

10. P. Li, X.F. Wang, W.Y. Gao, W. Yan. Analyst 143(2018). 